\title{
SPEECH ACT STRATEGY UTTERED BY EMMA WATSON AND MALALA YOUSAFZAI AS THE INSTRUMENT OF EMPOWERMENT
}

\author{
Ika SetyowatiSutedjo \\ Faculty of Culture, Universitas Airlang ga Indonesia
}

\begin{abstract}
Corresponding Author: Ika Setyowati S E-mail: ika.setyowati.sutedio-2019@fib.unair.ac.id

ARTICLE INFO

Received:2021-01-13

Accepted: 2021-03-20

Published: 2021-03-22

Volume: 5

Issue: 1

DOI:

https://doi.org/10.33019/lire.v

$3 \mathrm{i} 2.103$

KEYWORDS:

Speech act, Emma Watson,

malala yousafzai, women's

empowerment

ABSTRACT

Women's voice has been heard by the society for the past few years. There are a lot of movements created by women to support each other, for example Women's March, Time's Up, \#MeToo and HeForShe. This movement will lead to more recognition of women in va rious ex pertise. Consequently, those amazing women are able to meet in one situation. Certain situation leads women to do a conversation. The conversation between women also includes different kinds of speech act. This study aims to find the speech act uttered by Emma Watson and Malala Yousafzai as the instrument of empowerment. The result of the study shows that Emma Watson and Malala Yousafzai a re mostly use directive speech act in their speeches. The purpose of directive speech act is to make people to do something. Emma and Malala use directive speech act to empower people to accomplish something. The use of directive speech act also related to the third wave feminism movement. This movement establishes women to be bold, empowered, and brave. So, third wave of feminism also influences Emma and Malala as bold and empowered women. They empower other people to do something through their speech a ct because they a re empowered women.
\end{abstract}

\section{INTRODUCTION}

Women have already had their own voice in the past few years (Gannet, 1992). Even though it is really hard for women to be heard in the society, but it is starting to change (Domingo, et al., 2015). Women's voices can be heard both figuratively and literally now (Poynor, 2016). One of the biggest movements created by women is Women's March. This movement is happened after the election of the President of America, Donald trump. This movement grows as one of the inspiring social change and social leadership movement (Just \& Muhr, 2018). Women's voice has also started to be heard in the male dominated industry, for instance in music industry, entertainment, and politics.

Women's voice in the music industry is important to express oneself experience. Joan Baez and Mercedez Sosa are two of the protest singers who embody the duality of female representation. The dualities are maternal and virginal figures (Turnwald, 2018). Furthermore, women's voice becomes one of the tools to perform experiences. "Me and My Gun" is one of the songs written by Tori Amos who is a rape survivor. She is able to deliver her experience through her song. Her 
song is described as her self-expression to claim power (Hamessley, 2006). Stella Donnelly is also one of the musicians who speak up about women's rights in her album "Beware of The Dogs". "Old Man" and "Boys will be Boys" are two of her song that she wrote which describe about her friend's experience in rape case and she helps her friend through that situation. Beware of the Dogs is Stella Donnelly's expression towards toxic masculinity. Rollingstone describes her album as one of the masterpieces in \#metoo movement (Dolan, 2019).

Women's voice in entertainment industry is beginning to heard. \#Metoo movement is one of the movements that created by women. This hash tag was originally created in 2017 to convey the sexual assault and sexual harassment in the workplace. Furthermore, this hash tag is also made against the film producer Harvey Weinstein. (Bell, Meriläinen, Taylor, \& Tienari, 2018). \#MeToo movement is followed by Time's Up Movement. There is another of the movement in Hollywood called “Time's Up!". Time's Up is a feminist movement against sexual harassment, sexual assault and inequality in the workplace. This movement is founded in January 2018 as a response to sexual abuse case in Holly wood film industry (Bell, Meriläinen, Taylor, \& Tienari, 2018). This movement is started from women in the entertainment industry who demand equality for women working in service industry and agriculture industry (Clair, et al., 2019).

Female leaders are become role models for other women in wreck the stereotypic judgment (Blumenau, 2019). Female leaders provide an example of success for other women (Asgari, Dasgupta, \& Piscke, 2010), (Dasgupta \& Asgari, 2004). The first example is that women in education field can influence student's improvements in educational achievements (Nixon \& Robinson, 1999) and communication between both parties (Brajer \& Gill, 2010). The second example is that female politicians have increased participations of other women in elections (Beaman, Duflo, Pande, \& Topalova, 2012).

One of the ways for women to deliver their perspective and opinion is through speech. Women can also influence other people to do something also through their speech. So, speech is an essential tool for women to deliver their voice. Based on Austin (1962), speech is one of the ways to deliver information to other people. Speech is also an action that can make change. We are able to persuade, invite, command, or do anything else through speech. Each action has a specific purpose. A speaker should have a resource toward certain issue. She or he can command 
or deliver the issue to the right people and the right context in order to achieve the goal (Herbert, 2019).

The writer wants to examine more about the kinds of speech acts uttered by Emma Watson and Malala Yousafzai met at the premier of Malala new documentary movie called "He Named Me Malala" in 2015 (White, 2015), (Claire, 2016). So, this study is also going to analyze the empowerment instrument included in the speech act uttered by both speakers.

\section{LITERATURE REVIEW}

This research is using pragmatics approach, especially speech act by Searle (1976) to interpret meaning and analyze the data. There are several types of speech acts, one of them is illocutionary act. So, this research is focused on the types of illocutionary act.

\subsection{Speech Act}

Speech act in an important entity in pragmatics (Angelina, 2017). It is because speect act conveys a meaning or a message from the speakers to the hearer (Savira, 2019). Speech act also explains one actions toward another in making a communication through language. The expression of specific utterance can be identified as doing an action (enjoining, affecting) when uttering something (Angelina, 2017). Speech act theory is about uttering something to act something (Austin, 1962).

Speech act has different functions and purposes. Declaratives ask the audience to relate the truth-claim with their belief structure. Command or directive act requires the audience to do something. Command needs certain authority, context and toward certain person. Command is agent-relative. It requires specific authority condition in order to be successful. On the other hand, speech act is agent-neutral. Anyone may use it regardless the person has power or authority in the context or not (McDonald, 2020).

Searle classified speech act into three categories (Searle, 1969). The first is locutionary act. The second is illocutionary act. the third is perlocutionary act. Locutionary act is the act of expressing something. This speech act is doing a grammatical utterance (Searle, 1969). The meaning of lucotionary act is similar with words in dictionary (Angelina, 2017). Illocutionary act is one of the speech act that give or inform something to the listen ers (Searle, 1976). The actions of illoctionary act are reports, orders, request, alerts, questions, reports, and so on (Savira, 2019).

\section{(c) $\underset{B Y}{\text { (P) }}$}


Perlocutionary act is the act of giving effect or power to the listeners (1969). The effects are happy, sad, worried, anxious, dissapointed, and so on. This study focuses on the speech act strategy uttered by the speakers, especially in illocutionary act.

\subsection{Illocutionary Act}

Illocutionary act is the act of performing a communictive purpose to the addressee (Yule, 1996). One utterance includes two purposes, such as informing something and declaring to do something (Searle, 1976). The context is an important part in identfying this kind of speech act. Illocutionary act happened in appropriate intention and context. Illocutionary act often indicate as The Act of Doing Something (Angelina, 2017). There are some intention behind every utterance, for example the function of request, agreement, warning, question, command, blessing, respoting, and so on.

There are five kinds of illocutionary act, such as declaratives, expressives, dirctives, commisives, and representatives (Searle, 1976).

\section{Declaratives}

Declaratives is one of illocutionary act that aim to generate new circumstances or new status. The sentences of this type of illocutionary act are blessing, naming, firing, lifting, baptizing, pointing, punishing, canceling, deciding, forgiving etc. One of the example of decalative is the declaration of husband and wife in a marriage ceremony. So, the situation is changed from a couple into a husband and a wife.

\section{Expressive}

Expressive is type of illocutionary act which signifies the addresser's psychological attitute toward the addressee. This classification shows the attitudes or feelings of the addresse, such as pleasure, happy, dislike, sad, adore, delighted, etc. The form of speeches are thanking, complaining, critizing, congratulating, hoping, apologizing, blaming, welcoming, deploring, flattering, giving compliment and condoling. 
3. Directives

Directive is the classification of illocutionary act that have intention meaning behind the utterance. The speakers want the listeners to do something. So, the purpose of this speech act is giving an effect to the listeners to perform an action. The examples of sentences are suggesting, asking, urging, forcing, ordering, defying, charging, daring, comanding, etc. The use of directive speech act also considers as face-threatening acts, because it may have a potential to damage the listeners needs (Tanako, 2005).

\section{Commisives}

Commisive is one of the form of illocutionary act that give limiattion of addresser's action. It means that the speakers have take action on what already mentioned in the speech. Commisive is similar with directive, but commisive emphasizes that the addresser should take action. The speeces that include in commisive are threatening, promising, vowing, intending, offering, and expression of ability.

\section{Representative}

Representative is one of illocutionary act that express a situation to the addressee. This category connects the truth of an utterance. So, the speakers should be responsible for what they are saying. The speeches that involve in this kind of illocutionary act are stating, suggesting, claiming, mentioning, reporting, telling, agreeing, speculating, asserting, concluding, describing, and so on.

\subsection{The Speech Acts in Women's Movement}

Speech act theory can helps us to have a better understanding about women's movement. There are two kinds of speech acts that received many attentions in the feminism's movement, especially in fourth wave movement. The speech acts are reporting and accusing. Those speech acts are included in representative speech act. The purpose of representative speech act is to express certain situation to the listeners based on the speakers' point of view (Searle, 1976).

\subsection{Speech Act's Role to Empower People}

Speech act is used to explore human's speech in order to accomplish something. Speech act theory has an ability to empower people in achieving certain goal (Hanna \& Richards, 2019). There is one of the studies that analyze the use of speech act in nine female executive in Japan.

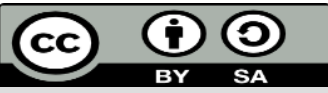


The number of professional women that play important role in leadership and authority is increasing in Japanese society (Tanako, 2005). So, Japanese women have to use communicative strategy in the way they are speaking. The purpose of this strategy is to show their power based on their occupational status. Japanese women are using directive speech acts in their utterances in order to create a comfortable conversation toward their peers. The use of directive speech act is effective to empower and support other people through a conversation (Tanako, 2005). Another study shows that female teacher uses directive speech act toward her student as a different strategy to adjust the socio-cultural norms to empower her students (Sumedi \& Rovino, 2020).

\subsection{Women Empowerment as a part of Women's Movement}

Everyone has every right to freedom. The freedom is including freedom of expression, freedom to give opinion without interference, freedom to seek and receive information, freedom to share information in any media, etc. These rights are included every race and gender (System, 2021). So, it means that women have every right to freedom. One of the ways to help women achieve their freedom is through empowerment. Empowerment is a process of realizing one selfauthority, increasing one capability, making positiv e change in one's life, creating awareness about undesirable situation, and changing perception toward something (Anonuevo \& Stromuist, 1995).

Women empowerment focuses on creating equal opportunity between women and men. So, women have resources, and opportunity to grow (Bayeh, 2016). Women can also contribute more in their community through empowerment. The purpose of women empowerment is to raise awareness of every woman to explore their ability (Myamba, 2010). Women empowerment has been a part of conversation since third wave of feminism until fourth wave of feminism. The most important concern in third wave feminism is sharing women's experience (Budgeon, 2011). The fourth wave of feminism acknowledges the movement through social media. One of the movement which happened in social media is Me Too movement. This movement concerns about sharing women's experience about sexual assault and sexual harassment that they received. So, the most important point in women empowerment in women's movement is sharing stories and experiences.

\section{MATERIAL AND METHOD}


This research is using descriptive qualitative method to analyze the data. Source of the data is an interview between Emma Watson and Malala Yousafzai at the premiere of Malala's new documentary film "He Named Me Malala" in 2015. Technique of data collection is divided into some part. The first is finding the video of an interview between Emma Watson and Malala Yousafzai in Youtube. The second is downloading the video. The third is transcripting the interview. The next step is collecting the data that include illocutionary act in the conversation. Technique of data analysis is separated into several steps. The first is identifying the utterances that already transcribed. The second is classifying the data based on illocutionary act theory by Searle (1976). The third is analyzing and describing the politeness strategy of both speakers. The next is interpreting the result of the data analysis. The last is making a conclusion based on the findings. This study uses the speech act theory to examine the its role to empower people.

\section{RESULTS}

There are several types of illocutionary act appear in an interview between Emma Watson and Malala Yousafzai. The first is expressive. The second is representatives. The third is commisive. The fourth is directives.

\subsection{Emma Watson's Speech Acts}

There are several speech acts uttered by Emma Watson in her speech. The speech act spoken by Emma Watson is described in Table 1.

Table 1. Illocutionary Acts spoken by Emma Watson

\begin{tabular}{l|l}
\hline \multicolumn{2}{c}{ Illocutionary Acts of Emma Watson } \\
\hline Representatives & 25 \\
\hline Directives & 27 \\
\hline Commisives & 0 \\
\hline Expressive & 18 \\
\hline Declaratives & 0 \\
\hline Total & 70 \\
\hline
\end{tabular}

Table 1 shows that there are 70 utterances of Emma Watson which include in Illocutionary Act. There are 25 representatives' sentences, 27 directives utterances, and 19 expressive sentences. Directives are the types of illocutionary acts that have most appearance. There are some categories of directives illocutionary act spoken by Emma Watson. The instances are asking questions, 
urging, describing, and asking for support. Expressive are the second illocutionary act that uttered by Emma Watson. The types of expressive illocutionary acts spoken by Emma Watson are feeling happy, feeling honored, feeling touched giving compliments, and thanking. The next is representative's illocutionary act uttered by Emma Watson. There are several sentences which catagorized as representative's illocutionary act. Those sentences are describing, giving opinion, agreeing, stating, concluding, and believing.

Table 1 presents that the kinds of speech acts that uttered the most by Emma Watson is Directive speech act (27 times). The most frequent kind of directive acts spoken by Emma Watson is asking questions. Emma Watson appears to be the interviewer in the context of the conversation and leads the conversation into certain goal. For instance;

"Do you have a sense of intangible goal that you would like to reach within your lifetime?"

"How does that feel to make your story shown on film and inspire thousands of young people today as part of the Into The Film Festival?"

"How would you respond to anyone who said that men can't be feminist or should be campaigning for girls rights?"

The directive act above shows that Emma Watson asks Malala several questions about her life, feeling, goals, and message to the audience. Emma Watson also leads the conversation with questions that related to Malala's life. The context of this conversation is a formal interview which conducted in one of the film festival. The film festival is called "Into the Film Festival". One of the movies in this festival is a movie about Malala personal life. So, Emma Watson as the interviewer leads the conversation about Malala's journey and more.

One of the questions asked by Emma Watson is about Malala's goal in her life. So, the conversation will encourage Malala to tell her story about her purpose in life. The second question is about Malala's feeling related to her current movie in the festival. Emma leads the conversation to Malala's personal feeling abouther movie that inspires a lot of young people. The third question is about Malala's message to men related to their view toward men cannot be a feminist. Emma asks Malala to empower men all around the world to fight for girls rights. Malala said

"if we wantequality... men have to step forward ... we have to work together. That's how change will come." 
Malala empowers men to take a step forward and work together to achieve equality. Malala responds that if men and women are working together, change will come. So, the directive acts which uttered by Emma Watson leads to the Malala personal opinion about something that can empower other people to do something.

Other types of directive act uttered by Emma Watson is urging and asking for support. The example of Emma Watson speeches are;

"we really need you as the next generation to extend the hand to the girls and women in your life"

"you are in a unique position, you have a unique opportunity to do that, to support girls and women in your life."

"if you have the chance, if moment represented to you, so speak up, so raise your voice"

"your help and support is greatly greatly appreciated"

The first until the third sentences are the types of directive acts called urging. Emma Watson urges boys and men all around the word to support girls and women in their life. Emma argues that boys and men have a unique position. So, Emma empowers them to speak up and support girls and women. Emma also says that their support and help are very much appreciated. It means that she does not only empower boys and men to do something, but also appreciate every single help that they do.

\subsection{Malala Yousafzai's Speech Acts}

There are several speech acts which included in Malala Yousafzai's speeches. The kinds of speech acts uttered by Malala Yousafzai can be seen in Table 2 .

Table 2. Illocutionary act uttered by Malala Yousafzai

\begin{tabular}{l|l}
\hline \multicolumn{1}{c}{ Illocutionary Acts of Malala Yousafzai } \\
\hline Representatives & 31 \\
\hline Directives & 57 \\
\hline Commisives & 8 \\
\hline Expressives & 19 \\
\hline Declaratives & 0 \\
\hline Total & 115 \\
\hline
\end{tabular}


Table 2. gives us some total numbers of Illocutionary act spoken by Malala Yousafzai. There are 113 sentences that Malala said in the interview. Representatives are the types of illocutionary act that occur the most in the interview. Representatives illocu tionary act appear 31 times. There are some sentences which involved in representatives illocutionary act, such as describing, stating, believing, claiming, speculating, agreeing, correcting, telling, giving opinion, and giving advice. Directives illoutionary act are the second most appear in the utterances of Malala Yousafzai. There are some utterances which include in directives illocutionary act, for instance urging, doubting, suggesting, asking questions, stating, and defying. However, Malala said less expressive illocutionary act than Emma Watson. The sentences that include in expressive illocutionary act are feeling honor, feeling excited, feeling inspired, feeling happy, hoping, and giving compliment. The last is commisive utterances. Malala said sev eral sentences which describe commisive illocutionary act, such as expression of ability and promising.

The most frequent speech act spoken by Malala Yousafzai is directive act (57 times). The type of directive acts uttered by Malala are doubting, urging, stating, defying, suggesting, and asking questions. So, it means that Malala mostly uses directive acts to express her opinion toward something. Urging is one of directive acts stated by Malala. She said;

"I want to see every child to get equality education. And in order to make sure that their dreams come true, we have to work hard and we have to take action"

"If we want equal rights for men, men have to step forward"

"We all have to work together. That's how change will come"

"It is really important that we are going together. We support each other"

"It is important that we think it is our responsibility to participate actively in bringing change. It's we who can bring change.

The first statement shows that Malala has a dream to see every child to go to school. However, she cannot work alone to make her dream comes true. So, she empowers people to work and take action together. She uses the word "we" to include people in her speech. She states her dreams and uses the word "we" to include people in her dreams. She said "we have to make sure". It means that Malala urges people to make sure that her dream becomes many people's dream. She uses that to empower people to work together with her. The last statement explains about the reason of her word choice. Malala believes that change is people's responsibility. She also adds that it is "we" 
who can bring change. She explains that it is essential to think that change will happen if people are working together.

Those statements are Malala's opinion about certain issue. Malala empowers people to step forward, take action, work hard, support each other, and bring change. Her statements are including that people are an essential part of change. So, she uses directive acts as a part of speech act to empower people achieving her dreams and becoming a part of change. Another type of directive act spoken by Malala is suggesting and hoping. The sentences uttered by Malala are;

"It is not just you watch the film, but you do something"

"I want this movie is not just to be a movie, but a movement"

The first sentence describes that Malala suggest people who watch the film and empower people to do something. She also hopes that her movie is not just a movie, but also a movement. Those sentences show that Malala empower people to do something through her speech act.

\section{DISCUSSION}

The result of the study shows that Emma Watson utters three types of illocutionary act. On the other hand, Malala performs four kinds of illocutionary acts. Directives illocutionary act are the styles of illocutionary act that appear the most in Emma Watson's and Malala Yousafzai's utterances. So, this study focuses on the directives illocutionary act to perform politeness. Directive is one of illocutionary act that give an effect to the listeners. This type is also aims to make the addressee perform the action which the addresser wants (Searle, 1976). There are some intended meanings behind every utterance which include in directives act (Maskuri, Tarjana, \& Djatmika, 2019).

The context of the utterances is important part of the speech event. It is because illocutionary act only occurs in convinient purpose and context. The context conversation between Emma Watson and Malala Yousafzai is in the formal interview. Emma Watson is interviewing Malala Yousafzai in "Into The Film Festival" as part of the premiere of Malala's new documentary film called "He Named Me Malala."

The result of the study reveals that speech acts that appear the most in the utterances of Emma Watson are directive acts. Most of the types of directive acts in Emma's utterances are asking 
questions. The purpose of directive acts is to make the hearer do what the speakers want (Searle, 1976). She plays an important role as the interviewer in the context of conversation. She makes Malala answer her questions through her directive acts. She also leads the conversation through her questions. The use of asking questions as the types of directive acts in Emma's utterances is not as the instrument of empowerment. However, the instrument of empowerment used by Emma Watson is through another type of directive acts, such as urging and asking for support.

On the other hand, Malala Yousafzai uses more directive acts (57 times) than Emma Watson (27 times). The kinds of directive speech act spoken by Malala are suggesting, urging, defying, doubting, stating, and asking questions. It shows that Malala uses various types of directive acts in her utterances to show her intentions toward other people. Based on the result of the study, Malala has a dream that she wants to see every child get a proper education. She is urging, suggesting, and stating that her dream is essential through her speech. So, she empowers people to work together with her to achieve that dream. She also says that working together and supporting each other are the only way to achieve change. She urges people not only sit and enjoy the movie, but also do something about it. She empowers people who watch her movie to be involved in a movement. It means that the use of directive speech act in her utterances aims to empower people to do something and bring change in the society.

Women empowerment has been a very essential topic since the third wave of feminism (Budgeon, 2011). Third wave of feminism indicates that women as the important part of the society, because they are powerful, emancipated, and highly individualized. This movement shapes women to be bold, volatile, and empowered and leads to characteristic of empowered women personalities (Harris, 2004). This movement also influences Emma Watson and Malala Yousafzai to be bold and empowered. These characteristic leads them to empower other people to do something that they are believed in.

\section{CONCLUSION}

Both Emma Watson and Malala Yousafzai are mostly using directive acts as the types of speech acts in their utterances. Emma Watson uses directive speech act to lead the conversation into more 
specific and explore many things about Malala. Malala uses directive speech act to empower people to work together and involve them to achieve her dreams. Malala uses speech act to empower people. This is related to the third wave feminism movement. Third wave of feminism focuses on women empowerment to achieve equality life. The third wave feminism influences Emma Watson and Malala Yousafzai to empower people to accomplish something together.

\section{ABOUT THE AUTHOR(S)}

The author is a Magister of Linguistics student in Universitas Airlangga, Surabaya.

\section{REFERENCES}

Angelina, J. (2017). Illocutionary Acts Used By Rodrigo Duterte in His Inagural Speech. Universitas Airlangga, English. Surabaya: Universitas Airlangga.

Anonuevo, C. M., \& Stromuist, N. P. (1995). Women, Education, and Empowerment: Pathways towards Autonomy. Report of the International Seminar (pp. 1-68). Hamburg: UNESCO Institute for Education.

Asgari, S., Dasgupta, N., \& Piscke, J.-S. (2010). When does contact with successful ingroup members change self-stereotypes? Social Psychology, 41(3), 203-211.

Austin. (1962). Performative Connotative, an Essay in the Philosophy of Language. Cambridge: Cambridge University.

Austin, J. L. (1962). How to Do Things with Words. Oxford: Oxford University Press.

Bayeh, E. (2016). The Role of Empowering Women and Achieving Gender Equality to the Sustainable Development of Ethiopia. Pacific Science Review B: Humanities and Social Sciences, 37-42.

Beaman, L., Duflo, E., Pande, R., \& Topalova, P. (2012). Female Leadership Raises Aspirations and Educational Attainment for Girls:A Policy Experiment in India. Science, 335(6068), 582-586.

Bell, E., Meriläinen, S., Taylor, S., \& Tienari, J. (2018). Time's Up! Feminist Theory and Activism Meets Organization Studies. Human Relation, 72(1), 4-22.

Blumenau, J. (2019). The Effects of Female Leadership on Women's Voice in Political Debate. British Journal of Political Science, 1-22.

Brajer, V., \& Gill, A. (2010). Yakity-yak: Who talks back? An E-mail Experiment. Social Science Quarterly, 91(4), 1007-1024.

Budgeon, S. (2011). Third Wave Feminism and the Politics of Gender in Late Moderinity. UK: Palgrave MacMillan. 
Clair, R. P., Brown, N. E., Dougherty, D. S., Delemeester, H. K., Geist-Martin, P., Gorden, W. I., et al. (2019, February 11). \#MeToo, Sexual Harassment: An Article, A Forum, and A Dream for the Future. Journal of Applied Communication Research, 93(8), 1-19.

Claire, M. (2016, February 3). Marie Claire UK. Retrieved March 24, 2020, from https://www.marieclaire.co.uk/news/emma-watson-interviews-malala-yousafzai-33611 Dasgupta, N., \& Asgari, S. (2004). Seeing is Believing: Exposure to Counterstereoty pic Women Leaders and Its Effect on The Malleability of Automatic Gender Stereotyping. Journal of Experimental Social Psychology, 60(5), 642-658.

Dolan, J. (2019, March 12). Rolling Stone. Retrieved March 24, 2020, from RollingStone: https://www.rollingstone.com/music/music-album-reviews/review-stella-donnellys-realtalking-indie-pop-gem-beware-of-the-dogs-807124/

Domingo, P., Holmes, R., O'Neil, T., Jones, N., Bird, K., Larson, A., et al. (2015). Women's Voice and Leadership in Decision-making. UK: Overseas Development Institute.

Gannet, C. (1992). Gender and the Journal: Diaries and Academic Discourse SUNY Series, Literacy, Culture, and Learning. State University of New York Press.

Hamessley, L. (2006). Women's Vpice Across Musical Worlds. Women and Music: A Journal of Gender and Culture, 95-99.

Hanna, N., \& Richards, D. (2019). Speech Act Theory as an Evaluation Tool for Human-Agent Communication. Algorithms, 1-17.

Harris, A. (2004). All About the Girl: Culture, Power, and Identity. London: Routledge.

Herbert, C. (2019). The Speech Actsof \#MeToo. APA Nwsletter, 16-20.

Just, S. N., \& Muhr, S. L. (2018). "Together We Rise": Collaboration and Contestation as Narrative Drivers of the Women's March. Leadership, 1-23.

Maskuri, K. D., Tarjana, S., \& Djatmika. (2019). Politeness Strategies in Directive Speech Acts in Local Indonesian Parliament Assembly Proceedings. International Journal of English Linguistics, 9(3), 85-94.

McDonald, L. (2020). Your Word Against Mine: The Power of Uptake. Synthese.

Mey, J. L. (1993). Pragmatics: An Introduction. Oxford: Blackwell.

Myamba, F. (2010). Achieving Gender Equality, Women's Empowerment and Strengthening Development Cooperation. New York: United Nations.

Nixon, L., \& Robinson, M. D. (1999). The Educational Attainment of Young Women: Role MOdel Effects of Female High School Faculty. Demography, 36(2), 185-194.

Poynor, F. (2016). Finding Their Voice: Women Musiciand of Baroque Italy. The Expositor: A Journal of Undergraduate Research in the Humanities, 70-79.

Savira, I. D. (2019). Illocuionary Act Found in Meghan Markle's Gender Equality Speech at UN Women. Universitas Airlangga, English. Surabaya: Universitas Airlangga. 
Searle, J. R. (1969). Speech Acts: An Essay in the Philosophy of Language. Cambridge: Cambridge University Press.

Searle, J. R. (1976). A Classification of Illocutionary Acts. Language Society, 1-23.

Sumedi, S. H., \& Rovino, D. (2020). Speech Act Analysis of English Teacher Talk at SMP Negeri 1 Rangkasbitung. Journal of English Language and Culture, 121-131.

System, U. N. (2021). Universal Dclaration of Human Rights. New York: Global Freedom of Expression. Columbia University.

Tanako, S. (2005). Re-Examining Linguistic Power: Strategic Uses of Directivesby Professional Japanese Women in Position of Authority and Leadership. Journal of Pragmatics, 633666.

Turnwald, E. (2018). "Thy Kingdom Come": Chatolism and The Nueva Cncion, 1966-1982. University of Dayton, Music. University of Dayton.

White, D. (2015, November 4). TIME. (T. Magazine, Producer) Retrieved March 24, 2020, from TIME: https://time.com/4100786/emma-watson-malala-yousafzai-feminism/

Yule, G. (1996). Pragmatics. Oxford: Oxford University Press. 